\title{
ЕКОНОМІКА УКРАЇНИ В УМОВАХ МОЖЛИВОГО ПЕРЕХОДУ СУСПІЛЬНИХ УКЛАДІВ РОЗВИТКУ ЛЮДСТВА В НОВУ ЯКІСТЬ
}

\author{
ЭКОНОМИКА УКРАИНЫ В УСЛОВИЯХ ВОЗМОЖНОГО \\ ПЕРЕХОДА ОБЩЕСТВЕННЫХ УКЛАДОВ \\ РАЗВИТИЯ ЧЕЛОВЕЧЕСТВА В НОВОЕ КАЧЕСТВО
}

\section{UKRAINE'S ECONOMY IN THE FACE OF THE POSSIBLE TRANSITION OF SOCIAL SETUPS HUMAN DEVELOPMENT IN NEW QUALITY}

В статті підтверджується, щуо глобалізаційні, насичені інформаційно-технологічними засобами комунікацій політичні й соціально-економічні світові процеси призвели до структурних цивілізаџійних змін на всій планеті. Складається враження, щуо традиційні підходи в політиці й економіці вичерпані, а нових не знайдено. Крім того, населення практично кожної краӥни світу не задоволено своїм життям і вже не хоче ні чекати, ні терпіти, щьо призвело до глобальної світової нестабільності в економічному розвитку як регіонів, так $i$ окремих країн. Висловлено припущення про межу розвитку суспільних історико-економічних укладів, яка виникла внаслідок взаємного впливу з останніми соціально-економічними й політичними подіями світової глобалізації. Цілком можливо, щуо людське суспільство стоїть на порозі безпрещедентного переходу до іншого якісного стану, щуо підтверджується скороченням тривалості суспільних історичних укладів розвитку людства. Проаналізовано зміни економічного середовища України протягом 2014-2015 років та підтверджено ї̈ загальні національні пріоритети. Тільки зважаючи на це Украӥна має шанси вижити як самостійна незалежна держава.

Ключові слова: суспільний уклад, глобалізаційні процеси, глобалізація світової економіки, національні пріоритети України, нова якість розвитку людства.

В статье подтверждается, что глобализационные, насыщенные информационнотехнологическими средствами коммуникачий политические и социально-экономические мировые процессы привели к структурным цивилизационным изменениям на всей планете. Создаётся впечатление, что традиционные подходы в политике и экономике исчерпаны, а новые не найдень. Кроме этого, население практически каждой страны мира не довольно своей жизнью и уже не хочет ни ждать, ни терпеть, что привело к глобальной мировой нестабильности в экономическом развитии как регионов, так и отдельных стран. Высказано предположение про гранищу развития общественных историко-економических укладов, которая возникла в следствие взаимного влияния с последними социально-экономическими и 
политическими событиями мировой цивилизации. Вполне возможно, что человеческое общество стоит на пороге беспрецедентного перехода к другому качественному состоянию, что подтверждается сокращением длительности общественно-исторических укладов развития человечества. Проанализированы изменения экономической среды Украины в 20142015 годах и подтверджены её общие национальные приоритеты. Только с учетом этого Украина имеет шансы выжить как самостоятельное независимое государство.

Ключевые слова: общественный уклад, глобализационные процессы, глобализация мировой экономики, национальные приоритеты Украины, новое качество развития человечества.

The article confirms that globalization, full of information and communications technology means political and socio-economic global developments have led to structural changes of civilization on the planet. It seems that traditional approaches in politics and economics exhausted, and newfound. In addition the population of almost every country in the world is not satisfied with their lives and do not want or expect or tolerate, leading to instability in the global economic development of both regions and individual countries. The article suggested the extent of social historical and economic setups development, which arose as a result of mutual influence with the latest social economic and political events in the world of globalization. We suggest that human society is on the verge of unprecedented move to another qualitative state, as evidenced by reduction in the duration of the social structures of historical development of mankind. Analysed the change of economic environment of Ukraine during the 2014-2015 and confirmed the common national priorities. Despite this only Ukraine has a chance to survive as a separate independent state.

Keywords: social setup, globalization, globalization of the world economy, Ukraine's national priorities, a new quality of human development.

Вступ. 3 кінця IX століття значна роль України в історичних світових процесах беззаперечна. Протягом чотирьох століть столицею Русі був Київ (як відомо 3 [1] назва Київська Русь започатковане з метою відрізнити саме той час) - найбільша у IX-XIII століттях країна Європи, що була транзитною країною "Із варягів у греки”. Це і боротьба за владу в Україні в 1917-1921 роках (як відомо уряд змінювався 14 разів), це й одна 3 найпотужніших світових економік світу, що входила у 70-80 роках XX століття до чільної десятки, це й найперспективніші в 1992 році з усіх 15 республік Радянського Союзу прогнози щодо подальшого суспільно-економічного розвитку нашої держави [2], це і сучасний стан в Україні, що співпав із вступом світу в час так званої глобальної нестабільності. На сьогодні наша держава, так само як і більшість країн світу, має необхідність реагувати не тільки на економічні, а й на політичні та соціальні виклики, поставлені перед нею останніми подіями зовнішнього та внутрішнього середовища [3]. Останнім часом у цих напрямках проведено деякі наукові узагальнення за участю зарубіжних, С. Кургіняна [4], Н. Смелзера [5] Т. Фрідмана [6], а також вітчизняних авторів В. Геєця [7], 3. Варналія [8], В. Гаврилюка [9] та деяких інших. 
Постановка завдання. Метою статті є з'ясування принципів взаємного впливу останніх світових науково-технічних досягнень й подій світової економічної глобалізації та новітніх соціально-економічних укладів розвитку людства.

Методологія. У роботі застосовано загальнотеоретичні методи системного підходу, історико-логічних узагальнень, порівняльного аналізу економічних показників між собою та статистичних методів, що дозволило обгрунтувати існуючий на сьогодні світовий історико-суспільно-економічний стан й припустити можливість переходу до іншого стану існування людства.

Результати дослідження. На сьогодні складається враження, що старі підходи в політиці й економіці вичерпані, а нових не знайдено. Населення практично кожної країни світу не задоволено своїм життям і вже не хоче ні чекати, ні терпіти. Такий стан суспільства неможливо описати мовою economics. Складається враження, що з допомогою сучасних новітніх технологій, які, так би мовити, «розігнали» світ до стрімких швидкостей, можна дійти до меж пізнання світу: вже сьогодні за допомогою мережі Інтернет не виходячи $з$ дому практично відразу можна одержати інформацію практично з першого-ліпшого питання, а за допомогою мобільного зв'язку поспілкуватися з іншою людиною майже з будьякої частини нашої планети. Полімізуючи з відомим американським журналістом Т. Фрідманом, який стверджує, що «...настає поєднання всіх світових центрів у єдину глобальну мережу, котра, якщо не втручається політика та тероризм, здатна стати першим вісником епохи непередбаченого процвітання та оновлення» [6] слід зазначити, що саме тероризмом й політичними катаклізмами характеризується уклад глобальної нестабільності. Що ж ще є характерним для зазначеного укладу?

По-перше, з точки зору медіа світ знаходиться на переломному моменті: нова цивілізація заснована на електронній системі комунікацій; книжну культуру, яка розвивалася протягом тисячоліть і почалася з Біблії та Корану, вже найближчим часом замінять інформаційні мережі Інтернет.

По-друге, комп'ютер поступово стає мовою почуттів й створюється фактично альтернативний віртуальний світ. Це дало змогу практично всім бажаючим, що раніше не мали змоги спілкуватися на рівних 3 «іншим» світом: інваліди, люди похилого віку, люди не «титульної» національності тощо, одержати бажану інформацію та скласти свою думку з будь-якого питання; в цих умовах для індивідів, принаймні для атеїстів та помірних віруючих, практично немає авторитетів, тому вони критично налаштовані і до сьогодення, i до минулого, i до 
майбутнього.

По-третє, глобалізація економіки з одного боку дала більші можливості у задоволенні потреб споживачів, але з іншого - породила такі потреби, що існує думка - для їх реалізації “потрібно вісім таких планет як Земля”, а можливості нарощувати споживання із-за обмеженості ресурсів, демографічних, екологічних проблем тощо світ не має можливості.

По-четверте, певна кількість вчених та фахівців-практиків в розвинутих країнах світу вважають, що комунікації взагалі й реклама зокрема, ставши, значною мірою, товаром, живуть своїм окремим життям, створюючи іллюзії реалізації мрій, свободи та в решті решт започатковуючи штучну іллюзію життя.

По-n'яте, створення новітніх та вдосконалення існуючих технологій в подальшому ставить під загрозу існування людини як такої, при чому це стосується всіх шарів й прошарків суспільства [5], особливо в умовах різкої поляризації майнового стану в більшості країн світу.

Тобто, не виключено, що з метою виживання людства, світ має перейти до нового якісного стану. Яким він буде й як відбуватиметься перехід в цей новий світ - еволюційно чи революційно - невідомо, але це має відбутися найближчим часом. Декілька років тому в авторській статті [10] було спрогнозовано, що світ (табл. 1), з середини 2010-2020 років вступить в епоху глобальної нестабільності, внаслідок тенденції скорочення часу існування суспільних укладів, пріоритети останніх з яких проіснували: індустріального приблизно більше трьох століть, інформаційно-технологічного - близько півстоліття, глобалізаційного - 12 років й вже два роки укладу глобальної нестабільності в економіці, політиці, кліматі тощо. За всю історію розвитку людства ще не було таких постійних структурних змін в країнах усього світу. 
Історично-інноваційний розвиток людства

\begin{tabular}{|c|c|c|c|c|c|c|}
\hline \multirow[b]{2}{*}{$\begin{array}{l}\text { Ном. } \\
\text { пор. }\end{array}$} & \multirow[b]{2}{*}{$\begin{array}{l}\text { Назва укладу за } \\
\text { класифікацією }\end{array}$} & \multicolumn{3}{|c|}{ Історичні періоди розвитку } & \multicolumn{2}{|c|}{ Населення } \\
\hline & & $\begin{array}{c}\text { Пріоритетне } \\
\text { існування }\end{array}$ & $\begin{array}{c}\text { Час } \\
\text { реалізації }\end{array}$ & $\begin{array}{l}\text { Термін переходу } \\
\text { до наступного }\end{array}$ & $\begin{array}{l}\text { Кількість, } \\
\text { млн. чол. }\end{array}$ & $\begin{array}{c}\text { Принцип } \\
\text { розселення }\end{array}$ \\
\hline 1 & $\begin{array}{l}\text { Збирання та } \\
\text { мисливство }\end{array}$ & $\begin{array}{l}\text { Від } 40 \text { тис. } p . \\
\text { до н.е. }\end{array}$ & $\begin{array}{l}\text { Близько } \\
30 \text { тис. } \\
\text { років }\end{array}$ & $\begin{array}{l}\text { Початок } \\
\text { древнього світу }\end{array}$ & До 10 & \multirow{2}{*}{$\begin{array}{l}\text { Децентра- } \\
\text { лізоване } \\
\text { розселення } \\
\text { людей }\end{array}$} \\
\hline 2 & Садівницькі & $\begin{array}{l}\text { До } 3 \text { тис. p. } \\
\text { до н.е. }\end{array}$ & $\begin{array}{l}\text { Близько } \\
8 \text { тис. } \\
\text { років }\end{array}$ & $\begin{array}{l}\text { Розквіт древньої } \\
\text { цивілізації }\end{array}$ & 50 & \\
\hline 3 & Аграрні & $\begin{array}{l}\text { XX до н.е. - } \\
\text { XVI ст. н.е. }\end{array}$ & $\begin{array}{l}\text { Близько } \\
2,5 \text { тис. } \\
\text { років* }\end{array}$ & $\begin{array}{l}\text { Відкриття } \\
\text { Америки }\end{array}$ & 400 & \multirow{2}{*}{$\begin{array}{l}\text { Центра- } \\
\text { лізація } \\
\text { зайнятого } \\
\text { населення }\end{array}$} \\
\hline 4 & Індустріальні & $\begin{array}{l}\text { XVII- } \\
\text { перша пол. } \\
\text { XX ст. }\end{array}$ & $\begin{array}{l}300-350 \\
\text { років }\end{array}$ & $\begin{array}{l}\text { Друга світова } \\
\text { війна }\end{array}$ & 3000 & \\
\hline 5 & $\begin{array}{l}\text { Інформаційно- } \\
\text { технологічні }\end{array}$ & $\begin{array}{l}\text { Сер. ХХ ст. } \\
-2000 \text { р. }\end{array}$ & $\begin{array}{l}\text { Приблизно } \\
60 \text { років }\end{array}$ & $\begin{array}{l}\text { Теракт } 11 \\
\text { вересня } 2001 \text { р. }\end{array}$ & \multirow[t]{3}{*}{$\begin{array}{c}\text { Близько } \\
7000\end{array}$} & \multirow{3}{*}{$\begin{array}{l}\text { Децентра- } \\
\text { лізація } \\
\text { розселення, } \\
\text { виробництв } \\
\text { та ін. }\end{array}$} \\
\hline 6 & $\begin{array}{l}\text { Глобалізація } \\
\text { економіки }\end{array}$ & $\begin{array}{l}\text { 2001-2013 } \\
\text { pp. }\end{array}$ & 10-15 років & $\begin{array}{l}\text { Світова криза } \\
\text { Події в Україні, } \\
\text { на Близькому } \\
\text { Сході, в Європі }\end{array}$ & & \\
\hline 7 & $\begin{array}{l}\text { Глобальна } \\
\text { нестабільність }\end{array}$ & $\begin{array}{l}\text { Починаючи } \\
32014 \text { р. }\end{array}$ & 2-3 роки & $\begin{array}{c}\text { Перехід людства } \\
\text { до нового } \\
\text { якісного стану } \\
?\end{array}$ & & \\
\hline
\end{tabular}

* - період з V до XV століття нашої ери (середні віки) виключено, як неефективний в інноваційному плані: децентралізація розселення населення, практичне припинення його зростання тощо.

На сьогодні, внаслідок подій в Північній Африці, Близькому Сході [4], в Україні і тепер вже в найрозвиненіших країнах Свропи (випадки вибухів та розстрілів людей протягом минулого року в Парижі, колективне гвалтування 
жінок в Кельні в новорічні свята тощо) всьому світу, зрозуміла криза в політиці, економіці та моралі, що наклалися на загальні цивілізаційні проблеми. Світ стає жорсткішим, все частіше згадуються чергові ознаки третьої світової війни, замість бажання зберегти природу, відновлюється боротьба за ресурси з одночасними діями США, що намагаються закріпити за собою однополярний світ (заради дестабілізації економічного стану в Росії, відновили видобуток нафти 3 власних родовищ, заблоковані свого часу з метою повернення до них в разі вичерпання видобутку даної сировини у традиційних країн-експортерів). Невільно спадає на думку прогнозований за календарем майя кінець світу, датований 2012 роком, та т. ін.

На ситуацію глобальної нестабільності в Україні наклалися суто вітчизняні проблеми. Чи $є$ змога з'ясувати, яким напрямком найближчим часом йтиме розвиток людства, зокрема у галузі економіки, та чи зможе України, з огляду на існуючі реалії, знайти в ньому гідне місце. Реалії сьогодення в Україні такі. Життєві стандарти різко погіршилися: курс гривні відповідно світової та європейської валют знизився втричі, основні продукти споживання подорожчали в 2,2-2,5 рази, комунальні платежі збільшилися в кілька разів тощо. Узагальнюючи наведені дані можна стверджувати, що приблизно втричі знизився життєвий рівень українців. Статистика двох останніх років взагалі провальна [11]: падіння експорту внаслідок ускладнення стосунків з країнами СНД, що аж ніяк не компенсують мінімальні квоти поставок до СС, якого цікавлять тільки сировина, матеріали та напівфабрикати (це “закріпить" в подальшому вузьку сировинну спрямованість експорту України до Свропи), замість продукції глибокої переробки, з високою добавленою вартістю, чим славилася Україна в другій половині минулого століття. Як наслідок, різке падіння чистого прибутку вітчизняної промисловості (табл. 2), внаслідок чого товаровиробники опинилися на межі банкрутства (значну позитивну динаміку має тільки корпорація ROSHEN, якій вдалося більше ніж удвічі збільшити свої статки, про що наголошував в [12] іiї генеральний директор В. Москалевський, зокрема мережа відповідних фірмових магазинів ROSHEN у великих містах збільшилася в рази: на сьогодні в Києві 29 магазинів, у Харкові - 6, у Львові - 4, у Вінниці - 3), а бюджет України недораховується значних сум. 
Динаміка зміни чистого прибутку промислових підприємств України [11]

\begin{tabular}{|l|c|c|c|c|c|c|c|}
\hline \multirow{2}{*}{ Найменування показника } & \multicolumn{7}{|c|}{ Період спостереження, роки } \\
\cline { 2 - 8 } & 2008 & 2009 & 2010 & 2011 & 2012 & 2013 & 2014 \\
\hline $\begin{array}{l}\text { Сумарний чистий прибуток } \\
\text { промислових підприємств } \\
\text { України, млрд. грн. }\end{array}$ & 5,5 & $-14,2$ & 11,6 & 32,0 & 25,9 & $-4,5$ & $-87,7$ \\
\hline
\end{tabular}

Наприклад, найкрупніше підприємство Сумщини (у 80-х роках минулого століття було близько 22 тис. працюючих, а зараз менше 10 тис.) ПАТ «Сумське HВО ім. М.В. Фрунзе» 3 прибуткового в 2012-му році перетворилося на збиткове в 2013-2014 роках, а в 2015 опинилося на межі банкрутства. В цілому ж минулого року ВВП зменшився приблизно на $20 \%$, інфляція сягнула $48,7 \%$, а за січеньвересень спад у промисловості склав 16,6\%, на транспорті - 13-14\%, у будівництві - 24,6\%, в аграрному секторі - 5,3\%, у роздрібній торгівлі $22,3 \%$. Тобто можна зробити висновок, що позитивні зрушення в економіці, які відбулися після закінчення економічної кризи та PR-економіки ЮщенкаТимошенко в 2010 році, в 2014-2015 роках повністю нівелювалися завдяки поверненню положень PR-економіки Порошенка-Яценюка-Саакашвілі нових часів.

Зрозуміло, що відповідно до наведених цифр бюджет 2016-го року занижено в 2,5 рази, 3 метою, по-перше, задовольнити вимоги МВФ, який хоче підтвердження повернення кредитів, хоч борг України перед ним вже перевершив золотовалютний резерв країни (\$ 12,7 млрд.) [11], по-друге, отримати для українців такий бажаний безвізовий режим до Свропи, по суті із-за якого й відбулися події кінця 2013-го — початку 2014-го років.

Сподівання на відчутну користь кредиту МВФ - марні, як через високий відсоток плати за борги, так і з поглибленням торгівельної війни з Росією, які Україні наносять приблизно трикратні збитки, в порівнянні із збитками Росії (як відомо, за часів СРСР ВВП Росії складав 60\% від загальносоюзного, України $20 \%$ й останні 20\% - всі інші республіки разом). Тим більше, що держава, наприклад, практично віддала бізнесу транспортне сполучення 3 Росією, відмінивши залізничне сполучення до Криму й значно його обмеживши $з$ іншими російськими містами. Відразу ж на порядок збільшилася кількість так званих "нерегулярних" перевезень мікроавтобусами. Безумовно, можна вважати, що таким чином перші особи держави “віддячують” тим, хто свого часу привів їх до влади, але це повністю протирічить загальновідомому постулату, що політика $є$ 
продовженням економіки, а не навпаки. Крім того, бізнес завжди “проб'є” собі дорогу. Наведемо приклад 3 традиційно найросповсюдженішого в Україні продукту, горілчаних виробів. Це імпортний горілчаний бізнес (у 90-х роках минулого століття Україну наповнили закордонні спиртні напої: горілка "Распутін”, солодкі сидри замість місцевих шампанських вин тощо, котрі, як тільки запровадили акцизний збір, відразу ж зникли з ринку, давши дорогу вітчизняному товаровиробнику [13]), тіньовий бізнес (немає сумніву, що після прийняття рішення про подвійне збільшення відповідного податку, яке у 2016 році підвищить ціну на спиртні напої ще на 15-25\% для вітчизняного споживача, - відразу ж пожвавиться самогоноваріння й держава в цілому не тільки не одержить додаткових надходжень до бюджету, а вони тільки зменшаться) або кримінальний бізнес (недорогий самогон невідомого походження, підроблена та контрабанда горілка, незаконна нічна торгівля тощо). Є невелика надія на ефективність боротьби з корупцією, але й вона марна, як й надія на результативну адміністративну реформу, що де-факто спрямована не на розширення повноважень місцевого самоуправління, a на їх обмеження 3 одночасним зміцненням президентської вертикалі [14] (перші кроки, як от примусова перереєстрація деяких успішних підприємств до центру, переведення закладів середньо-технічної й середньо-спеціальної освіти на місцеві бюджети та деякі інші, не надихають) чи нову поліцію, закупівля тільки нової форми для якої за словами міністра внутрішніх справ А. Авакова у вітчизняних ЗМІ обійдеться на суму в 900 млн. грн.

3 іншого боку постійні скарги малого та середнього бізнесу, як правило, безпідставні: в розвинути країнах також супермаркети фактично перетворилися у торговельно-розважальні центри, куди поступово переміщуються так звані “молодіжні тусовки”, а малий бізнес залишається так би мовити “на підхопленні”, практично не полишаючи своєї споживчої ніші й здебільшого використовуючи концентровану маркетингову стратегію охоплення ринку. Наприклад, на території практично всієї Україні вдосталь магазинів, кафе тощо й закриття чи відкриття чергового аж ніяк не позначається на зручностях населення. Навпаки, останнім часом все більше втрачають державні установи, наприклад, послуги "Нової пошти" поступово замінюють послуги державної, а відмінене державою залізничне сполучення відразу ж підхопили приватні автомобільні перевізники.

Але вищенаведене і $є$ ринкова економіка. Так, якщо на межі 80-90-х років минулого століття існуючий де-факто в торгівлі, ресторанному, отельному, туристичному бізнесі маркетинг легалізувався де-юре, орієнтуючись на елементи комплексу маркетингу promotion i position (place), які раніше практично не застосовувались, то в промисловості все довелося починати з нуля. На сьогодні ті підприємства, яким вдалося здійснити головним чином інноваційні зміни, 
зберегли або незначно знизили обсяги виробництва своєї продукції. Пожвавлення ж невиробничих сфер діяльності людини в порівнянні з 1990 роком зумовило збільшення кількості працюючих у них: у торгівлі приблизно у 2,5 рази, в банківській діяльності та операціях 3 нерухомістю більше ніж утричі та бюджетній сфері в півтора рази [11], спонукає перехід орієнтованих на ринкову економіку фахівців (маркетологів, рекламістів, логістиків, PR-щиків, біржовиків, менеджерів [9]) в ці сфери життєдіяльності людини.

Отже ситуація в Україні значної мірою вписується в сучасну світову глобальну нестабільність, яка складається з сукупності політичних, економічних, демографічних, соціальних та екологічних проблем, помножених на обмеженість природних ресурсів. Стає все наявнішим, що розвиватися "попереднім чином" світ більше не має можливості. Першими це зрозуміли японці.

Відповідно до вищенаведеного за загальними підсумками IV-ї Міжнародної науково-практичної конференції “Сучасні виклики розвитку світової економіки”, що відбулася у КНУ ім. Т. Шевченка, 19-20 листопада 2015 року [15] для України було узагальнено такі загальнонаціональні пріоритети як наука, освіта, промисловість, сільське господарство, військова справа, охорона здоров'я та пенсійне забезпечення $[7,8]$. Тут єдиним запитанням залишається лише таке - де взяти на все це гроші?

Висновки. В дослідженні проаналізовано взаємний вплив останніх соціально-економічних й політичних подій світової глобалізації та розвиток суспільних історико-економічних укладів. Висловлено припущення, що людське суспільство стоїть на порозі безпрецедентного переходу до іншого якісного стану, що підтверджується скороченням тривалості суспільних історичних укладів розвитку людства. Підтверджено, що глобалізаційні, насичені інформаційнотехнологічними засобами комунікацій політичні й соціально-економічні світові процеси призвели до структурних цивілізаційних змін усієї планети i, як наслідок, - до глобальної світової нестабільності в економічному розвитку країн. В цих умовах протирічь глобалізації, економічних криз та політичних подій у світі Україна має на основі загальнонаціональних пріоритетів збалансувати внутрішньо орієнтовану економіку та домогтися принаймні паритету в зовнішній торгівлі.

Науковою новизною $\epsilon$ припущення про досягнення межі у розвитку суспільних історико-економічних укладів, що підтверджується останніми світовими науково-технічними інноваціями, соціально-економічними й політичними подіями світової глобалізації. Ідея можливості переходу людського суспільства до іншого якісного стану розвитку людства $\epsilon$ перспективним напрямком подальших наукових досліджень в економіці та соціології. 


\section{Література:}

1. Ключевский В. Курс русской истории / В. Ключевский // Сочинения в девяти томах. — М., 1987-1990.

2. Телєтов О. В чому помилився “Дойче Банк” / О. Тєлєтов // Червоний промінь, 1992. — № 52 (4024) від 26 грудня..

3. Тєлєтов О.С. Стан і проблеми в маркетинговій діяльності в науці і освіті України / О.С. Тєлєтов //Економічний вісник НТТУ “КПІ”, №11, 2014. - С. 435-439.

4. Кургинян С. Российско-украинские отношения - от ситуативной прагматики к полноценной стратегии. http://kurginyan.ru/publ.shtml? $\mathrm{cmd}=$ art\& theme $=12 \&$ auth $=\& \mathrm{id}=2316$

5. Смелзер Н. Социология / Н. Смелзер // пер. $з$ англ - М. : Феникс, 1994. - 688 c.

6. Фридман Томас. Плоский мир: краткая история XXI века / Фридман Т. // М. : АСТ Москва. — 2007. $608 \mathrm{c}$.

7. Пріоритети національного економічного розвитку в контексті глобалізаційних викликів : монографія / за ред. В.М. Гесця, А.А. Мазаракі // — К. : Київ. нац. торг-екон. у-т, 2008. — 389 с.

8. Державна регіональна політика України: особливості та стратегічні пріоритети: монографія / за ред. 3.С. Варналія. - К.: НІСД, 2007. - 768 с.

9. Гаврилюк В. Я. Особливості розвитку та діяльності ВНЗ у глобальній економіці / В.Я. Гаврилюк // Вісник Національного університету “Львівська політехніка" : Менеджмент та підприємництво в Україні : Етапи становлення та проблеми розвитку. — Львів, НТУ “Львівська політехніка”. — 2013. — № 769. C. $405-412$.

10. Тєлєтов О.С. Інновація та розвиток людства. Історія і сучасність / О.С. Тєлєтов // Маркетинг i менеджмент інновацій - 2011. - № 4. - С. 13-24.

11. Офіційний сайт державної служби статистики України [Електронний ресурс] / Державна служба статистики України. — Режим доступу : http: // www.ukrstat.gov.ua/.19.07.2014.

12. http://m.liga.net/biz/prodovolstvie/265629-partner_prezident...

13. Зозульов О.В. Моніторинг ринку алкогольних напоїв міста Києва / О.В. Зозульов // Маркетинг в Україні. - 1999. - № 2. - С. 11-13.

14. Тєлєтов О.С. Маркетинговий підхід до вирішення проблем адміністративної реформи в Україні / O.С. Тєлєтов // Ринково-орієнтоване управління інноваційним розвитком : монографія / за ред. д.е.н., професора С.М. Ілляшенка. - Харків : ТОВ «Діса плюс», 2015. - С. 81-88.

15. Сучасні виклики розвитку світової економіки : Збірка матеріалів IV Міжнародної науково-практичної конференції 19-20 листопада 2015 року. - К. : КНУ ім. Т. Шевченка, 2015. 